\title{
Effect of the Chemical Composition of Simulated Body Fluids on Aerogel-Based Bioactive Composites
}

\author{
Enikő Gyơri, István Fábián and István Lázár * \\ Department of Inorganic and Analytical Chemistry, University of Debrecen, Egyetem tér 1 H-4032, Hungary; \\ gyori.eniko@science.unideb.hu (E.G.); ifabian@science.unideb.hu (I.F.) \\ * Correspondence: lazar@science.unideb.hu; Tel.: +36-(52)-512900-22376
}

Received: 16 October 2017; Accepted: 23 November 2017; Published: 27 November 2017

\begin{abstract}
Replacement of damaged or missing bone tissue is a serious problem in orthopedic surgery. Although various artificial materials are available, none of them fulfil the requirements completely. In this study, new bone substitute materials, silica aerogel-based $\beta$-tricalcium phosphate, and hydroxyapatite composite ceramics, along with a control sample were synthesized and tested. Porosities and pore size distribution curves were determined by nitrogen gas adsorption/desorption porosimetry, and surface morphology changes were studied by scanning electron microscopy. Bioactivities were tested in vitro by soaking the samples in simulated body fluids (SBF). Three new advanced SBFs containing eight essential amino acids and bovine serum albumin were developed, extending the complexity of the original simulated body fluid in order to approximate the human blood plasma's composition more accurately. Each sample was treated with SBF1-SBF4 for two weeks. According to our results, it seems to be necessary to re-evaluate hydroxyapatite deposition as proof of bioactivity of artificial bone substitutes when synthetic body fluids analogous in their composition to human blood plasma are used in studies.
\end{abstract}

Keywords: silica aerogel-based bioceramics; artificial bone substitute composite; simulated body fluid; assessment of bioactivity; hydroxyapatite deposition

\section{Introduction}

The human skeleton may be damaged by injuries, traumas, infections, tumors or age-related changes resulting in significant loss of bone mass and volume [1]. The current surgical techniques and methods use autologous bones and bone matrices from scarcely available natural sources, as well as artificial materials, which do not suffer from limited availability [2-4]. Bone substitutes should, as a minimum requirement, show high biocompatibility and adequate mechanical strength. The modern materials have bioactive surface and open macroporosity, to provide the necessary space for vascularization and bone tissue ingrowth. The latest generation of functionalized bioactive bone substitute materials promotes new bone formation, catalyzes the regenerative mechanism of the body as a result of the great mechanical strength take over the supporting function of the skeleton and, due to their resorbable nature, makes complete regeneration of the original tissue feasible $[5,6]$.

Several types of materials known from the literature are used for hard tissue engineering [7-10]. The most widely used ones are bioactive glasses [11-15], calcium phosphate-based cement and ceramics, biodegradable polymer-based composites, and special alloys ( $\mathrm{Ti}, \mathrm{Zr}$ ) etc. [16-21]. All the materials have numerous advantages but none of them fulfil the requirements completely.

Most recently, a new type of artificial bone substitute materials, silica aerogel-based composites containing calcium phosphates guest particles, have been developed. They combine the advantageous bioactivity of calcium phosphate ceramics with the very high porosity and permeability of the aerogel structures and the induction of type I collagen formation by the silicate ions [22-24]. Animal studies 
showed promising bone regenerative activity, while adhesion and proliferation of SAOS2 cells on the surface might indicate potential therapeutic use. A further advantage of the aerogel matrix is that the mechanical strength of the grafts can be tailored by heat treatment in the 5-110 MPa region, and the macro- and mesoporosity may be tuned from a few nanometers to a millimeter scale [25-27].

Artificial materials intended for clinical use are studied by in vivo and in vitro methods in simulated body fluids (SBF) to evaluate their biocompatibility [28,29]. In these model fluids, the ability of apatite formation on the surfaces can be tested. Most SBFs do not contain proteins, amino acids, or vitamins; only the inorganic ions of blood plasma are present in the same concentration as in the natural fluids. The tests may be either dynamic or static in nature. Taking the constant flow of the body fluids into consideration, the dynamic method might be considered a better way to evaluate biocompatibilities [30]. However, static tests are less complicated and widely accepted in the literature. Nevertheless, the results of these tests do not always match the results of the in vivo tests [31-33], which means that in order to evaluate the bioactivity of the artificial materials correctly, the in vitro experiments are not enough.

Another method to estimate biocompatibility is the use of stem cells [34-37]. Cell studies are much more expensive than the SBF experiments, and they require sterile laboratory conditions, qualified life scientists, and proper microscopy technique; but they may provide more accurate evidence of bioactivity.

It has been reported that adsorbed proteins can influence the dissolution and crystallization of different calcium phosphates. Studying these factors is very useful for a correct simulation of the in vivo conditions [38-40].

Here we report the surface behavior and hydroxyapatite formation ability of silica aerogel-based calcium phosphates composites in a series of new simulated body fluids. New SBFs, containing amino acids and bovine serum albumin, were designed to approximate the chemical environment of blood more accurately than before and used to study their effect on bioactive surfaces in vitro. Effects of the amino acid/protein content on the formation potential and morphology of hydroxyapatite layer deposition are discussed.

\section{Materials and Methods}

\subsection{Materials}

Methanol (technical grade), acetone (technical grade), and $25 \% \mathrm{~m} / \mathrm{m}$ ammonia solution (analytical reagent grade) were purchased from Molar Chemicals $\mathrm{Kft}$. (Halásztelek, Hungary). The inorganic salts $\left(\mathrm{NaCl}, \mathrm{KCl}, \mathrm{MgCl}_{2} \cdot 6 \mathrm{H}_{2} \mathrm{O}, \mathrm{CaCl}_{2}, \mathrm{Na}_{2} \mathrm{SO}_{4}, \mathrm{NaHCO}_{3}, \mathrm{~K}_{2} \mathrm{HPO}_{4}\right)$, tetramethyl orthosilicate (TMOS) (purum), $\beta$-tricalcium phosphate (purum), hydroxyapatite (puriss), urea (reagent grade), microcrystalline cellulose, and bovine serum albumin (assay $\geq 98 \%$ ) were obtained from Sigma-Aldrich (St. Louis, MO, USA). Tris(hydroxymethyl)aminomethane (TRIS) (analytical reagent grade) and the applied amino acids (GA, Ala, Gly, Pro, Leu, Lys, Ser, Val) (analytical reagent grade) were purchased from Reanal Finomvegyszergyár Kft. (Budapest, Hungary). Kanamycine sulphate monohydrate and gentamicin sulphate were obtained from Duchefa Biochemie B.V. (Haarlem, Netherlands). DI water was prepared by a MilliQ instrument and sterilized by boiling for $10 \mathrm{~min}$. All vessels used in the SBF studies were steam-sterilized prior to use.

\subsection{Preparation of Silica Aerogel-Based Composites}

The samples were prepared by the base-catalyzed sol-gel technique [41]. The following general recipe was applied for the preparation of the samples containing a mixture of tricalcium phosphate and hydroxyapatite as additives in 1:1 ratio. First, two solutions (' $\mathrm{A}$ ' and ' $\mathrm{B}$ ') were prepared. Solution $\mathrm{A}$ was made of $45.0 \mathrm{~mL}$ (1.112 mol) methanol, $8.00 \mathrm{~mL}$ ( $0.444 \mathrm{~mol})$ distilled water, $15.00 \mathrm{~mL}(0.113 \mathrm{~mol})$ diluted (1:1) $\mathrm{NH}_{3}$ solution (obtained by diluting $10.0 \mathrm{~mL}$ of $25 \% \mathrm{NH}_{3}$ solution with $10.0 \mathrm{~mL}$ water), and $30.0 \mathrm{~mL}(0.100 \mathrm{~mol})$ urea solution (obtained by dissolving $10.0 \mathrm{~g}$ urea in $50.0 \mathrm{~mL}$ methanol). 
Solution B contained $35.0 \mathrm{~mL}(0.865 \mathrm{~mol})$ methanol and $15.0 \mathrm{~mL}(0.102 \mathrm{~mol})$ tetramethoxysilane. Measurements of $2.50 \mathrm{~g}\left(8.06 \times 10^{-3} \mathrm{~mol}\right) \beta$-tricalcium phosphate, $5.00 \mathrm{~g}$ cellulose, and $2.50 \mathrm{~g}$ $\left(4.98 \times 10^{-3} \mathrm{~mol}\right)$ hydroxyapatite were added to solution A under intensive stirring. Solutions A and $\mathrm{B}$ were then mixed under vigorous stirring.

In order to avoid the aggregation of the additives, the sol was stirred until it turned very viscous, but gel setting had not yet begun. At that point, it was transferred into cylindrical plastic molds $(66 \mathrm{~mm} \times 28 \mathrm{~mm})$, then sealed with parafilm and allowed to gel at room temperature overnight.

A control sample free of active additives was prepared by the same manner. In that case, solution A contained $48.0 \mathrm{~mL}(1.186 \mathrm{~mol})$ methanol and $12.0 \mathrm{~mL}\left(8.13 \times 10^{-2} \mathrm{~mol}\right)$ TMOS, while solution B was made of $48.0 \mathrm{~mL}(1.186 \mathrm{~mol})$ methanol, $12.0 \mathrm{~mL}(0.667 \mathrm{~mol})$ distilled water, $8.0 \mathrm{~mL}(0.118 \mathrm{~mol})$ aqueous ammonia solution $(25 \% \mathrm{~m} / \mathrm{m})$, and $5.0 \mathrm{~g}$ cellulose.

After that, the samples were transferred to perforated aluminum frames which provided mechanical support for the gels and allowed a quick and efficient exchange of the solvents before supercritical drying. All gels were soaked in methanol-cc $\mathrm{NH}_{3}$ (8:1) and pure methanol-each for a day-in order to purify them and to remove water. Then methanol was gradually replaced by acetone, in $25 \%$ increments. Finally, gels were stored in a copious volume (2 L) of freshly distilled dry acetone for three days. The supercritical drying was carried out in a custom-made high-pressure reactor according to a general procedure published in our previous works [42,43].

The aerogels were calcined in a programmable temperature furnace in order to achieve suitable mechanical strength. First, cellulose and other organic components were burned out at $500{ }^{\circ} \mathrm{C} / 8 \mathrm{~h}$, next the temperature was raised at $100{ }^{\circ} \mathrm{C} / \mathrm{h}$ rate and kept for $1 \mathrm{~h}$ in each step, up to $1000{ }^{\circ} \mathrm{C}$ to provide sample S1000. The monolithic S1000 was cut in three, and two parts were transferred for further heat treatment. Sample S1050 was calcined at $1050{ }^{\circ} \mathrm{C}$ for $1 \mathrm{~h}$, and sample S1100 at $1100{ }^{\circ} \mathrm{C}$ for $1 \mathrm{~h}$. The samples were cut from the corresponding monolithic block with a diamond blade cutter. The control sample containing no calcium phosphates was calcined as described for $\mathrm{S} 1000$. Photographs of the as-prepared aerogel composites are in the Supplementary Materials, Figure S1.

\subsection{Characterization}

Nitrogen gas porosimetry measurements were performed on a Quantachrome Nova 2200e surface area and porosity analyzer (Quantachrome Instruments, Boynton Beach, FL, USA). The calcined pieces of samples were ground in a mortar and outgassed under vacuum at $300{ }^{\circ} \mathrm{C}$ for $3 \mathrm{~h}$ before the measurements. Adsorption-desorption isotherms recorded can be found in the Supplementary Materials, Figure S3.

Scanning electron micrographs (SEM) were recorded on a Hitachi S-4300 instrument (Hitachi Ltd., Tokyo, Japan) equipped with a Bruker energy dispersive X-ray spectrometer (Bruker Corporation, Billerica, MA, USA). The surfaces were covered by a sputtered gold conductive layer. A 5-15 kV accelerating voltage was used for taking high-resolution pictures.

\subsection{Simulated Body Fluid Compositions}

Four types of SBFs were prepared (denoted as SBF1, SBF2, SBF3, and SBF4). The composition of SBF1 was the same as that of the original solution given in the literature [29]. The original preparation process, however, is time-consuming and a little complicated, furthermore the storage life of the solution is limited. Thus, we applied the other method [44] and prepared two stock solutions (A and B) containing groups of the compounds, which cannot form a precipitate with each other and can be stored for several weeks in solution. First, Tris stock solution was produced by dissolving $1.2115 \mathrm{~g}$ tris(hydroxymethyl)aminomethane in distilled water and filled up to $100.0 \mathrm{~mL}$. Solution A was made of $\mathrm{NaCl}, \mathrm{KCl}, \mathrm{MgCl}_{2} \cdot 6 \mathrm{H}_{2} \mathrm{O}$ and $\mathrm{CaCl}_{2}$. Solution $\mathrm{B}$ contained $\mathrm{Na}_{2} \mathrm{SO}_{4}, \mathrm{NaHCO}_{3}$, and $\mathrm{K}_{2} \mathrm{HPO}_{4}$. The exact amounts of the salts and the chemical composition of the simulated body fluids are summarized in Table S1. 
To create SBFs with amino acids and bovine serum albumin (SBF3 and SBF4), first, a $100.0 \mathrm{~mL}$ stock solution of amino acids was prepared. Eight amino acids (glutamic acid, alanine, glycine, proline, leucine, lysine, serine, and valine) were dissolved and $1.00 \mathrm{~mL}$ of this solution was added to solutions $A$ and $B$ as well. The average concentration of serum albumin in human blood plasma is $35-50 \mathrm{~g} / \mathrm{L}$, thus we dissolved $4.0 \mathrm{~g}$ bovine serum albumin (BSA) in solutions A and B, in order to simulate the composition of the human blood plasma more accurately.

The $\mathrm{pH}$ of the stock solutions was set to 7.4 by adding $\mathrm{HCl}$ solution, as required. The masses of $\mathrm{HCl}$ given in the table are total masses added to solutions $\mathrm{A}$ and $\mathrm{B}$. To prevent bacterial infections, all types of SBFs were kept sterile by adding kanamycin in a concentration of $100 \mathrm{mg} / \mathrm{L}$ and gentamicin in a concentration of $50 \mathrm{mg} / \mathrm{L}$ as biocide agents in stock solutions A and B. All stock solutions were stored in sealed bottles in the dark. To prevent unwanted bacterial growth in the SBFs, two antibacterial agents Gentamicin and Kanamycin were added to the solutions. Figure S2 shows a scanning electron micrograph of a sample surface when bacterial infection occurred.

The final SBF solutions for biocompatibility studies were created by mixing equal volumes of solutions A and B directly before use. The $\mathrm{pH}$ of the SBFs was set to 7.4 after mixing, if necessary.

\subsection{In Vitro Study of Bioactivity}

Two granules (4-4.5 mg each) of each sample were soaked in the selected SBF solutions under static conditions for two weeks, in filled-up and hermetically sealed $4 \mathrm{~mL}$ glass vials. The weight/volume ratio was $0.001 \mathrm{~g} / \mathrm{cm}^{3}$, the volume/surface area ratio was $0.28 \mathrm{~cm}^{3} / \mathrm{mm}^{2}$, which is higher than that proposed by Kokubo et al. due to the porous structure of the samples [29]. The vials were thermostatted at $37^{\circ} \mathrm{C}$. After 14 days, the particles were rinsed thoroughly with distilled water, then with methanol, and allowed to dry under ambient conditions.

\section{Results}

\subsection{Porosity of the Samples}

Figure 1 shows the pore size distribution graphs of the samples determined by the Barrett-Joyner-Halenda (BJH) method, and the cumulative pore volumes as a function of the pore diameters. The wide peak maxima at about $30 \mathrm{~nm}$ (Figure 1a,b) shifted to the lower mesopore region (Figure $1 \mathrm{c}, \mathrm{f}$ ) when the samples were heated at $1000{ }^{\circ} \mathrm{C}$, and fell below $10 \mathrm{~nm}$ at higher temperatures for S1050 and S1100 (Figure 1d,e). In the latter cases, however, no characteristic pore size could have been determined. The specific surface area determined by the multipoint BET method (SBET) of the control sample (calcined at $1000{ }^{\circ} \mathrm{C}$ ) (Figure 1f) was $159 \mathrm{~m}^{2} / \mathrm{g}$, and the pore size distribution curve maximum was at $24 \mathrm{~nm}$. The parameters regarding the porosity of the samples are summarized in Table 1. The specific surface areas were determined by the Brunauer-Emmett-Teller (BET) method.

The size, weight, and density of the samples varied as well, as a result of the heat treatment. The increasing of the density is in good correlation with the decreasing porosity. From the initial $0.2 \mathrm{~g} / \mathrm{cm}^{3}$ the density increased to approximately $1.4 \mathrm{~g} / \mathrm{cm}^{3}$. The compressive strength of the sample S1000 heated at $1000^{\circ} \mathrm{C}$ was approximately $21 \mathrm{MPa}$, and $81 \mathrm{MPa}$ of the sample $\mathrm{S} 1100$ heated at $1100{ }^{\circ} \mathrm{C}$.

Table 1. Calculated parameters of the porosity of the samples. The specific surface area was obtained by the BET model, the pore size distribution and the pore volume were determined by the BJH method.

\begin{tabular}{ccccccc}
\hline Obtained Parameters & \multicolumn{3}{c}{ Samples } & \multicolumn{3}{c}{ Control Sample } \\
\hline Calcination temperatures: & $\mathbf{5 0 0}{ }^{\circ} \mathbf{C}$ & $\mathbf{1 0 0 0}{ }^{\circ} \mathbf{C}$ & $\mathbf{1 0 5 0}{ }^{\circ} \mathbf{C}$ & $\mathbf{1 1 0 0}^{\circ} \mathbf{C}$ & $\mathbf{5 0 0}{ }^{\circ} \mathbf{C}$ & $\mathbf{1 0 0 0}^{\circ} \mathbf{C}$ \\
\hline SBET $\left(\mathrm{m}^{2} \cdot \mathrm{g}^{-1}\right)$ & 331 & 76 & 9 & 4 & 540 & 159 \\
$d(\mathrm{~nm})$ & 32 & 14 & $\mathrm{n} / \mathrm{a}$ & $\mathrm{n} / \mathrm{a}$ & 32 & 24 \\
$V_{\text {total }}\left(\mathrm{cm}^{3} \cdot \mathrm{g}^{-1}\right)$ & 1.5807 & 0.321 & 0.0329 & 0.0113 & 1.6274 & 0.865 \\
$V_{\text {macropore }}\left(\mathrm{cm}^{3} \cdot \mathrm{g}^{-1}\right)$ & 0.1159 & 0.007 & 0.0022 & 0.0029 & 0.2066 & 0.01 \\
$V_{\text {meso-and micropore }}\left(\mathrm{cm}^{3} \cdot \mathrm{g}^{-1}\right)$ & 1.4648 & 0.314 & 0.0307 & 0.0084 & 1.4208 & 0.855 \\
\hline
\end{tabular}



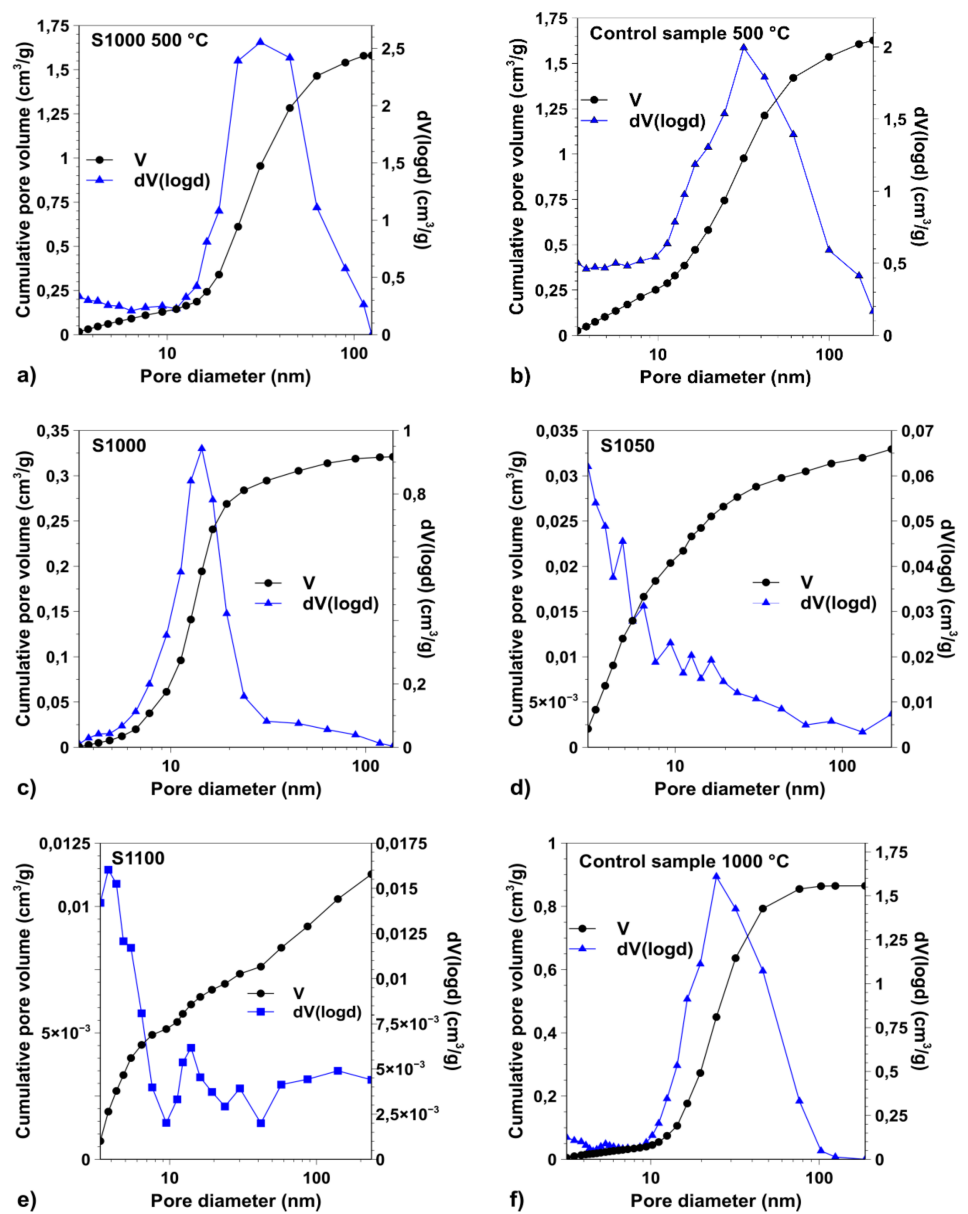

Figure 1. Pore size distribution $(\boldsymbol{\Lambda})$ and cumulative pore volume $(\bullet)$ curves determined by the BJH method. The samples calcined at $500{ }^{\circ} \mathrm{C}$ had a high specific surface area, but it decreased very significantly when the heating temperature was increased to 1000,1050 , and then $1100{ }^{\circ} \mathrm{C}$. The characteristic pore size could be determined from the pore size distribution curves, except for S1050 and S1100. The specific surface area of the control sample (calcined at $1000{ }^{\circ} \mathrm{C}$ ) was $159 \mathrm{~m}^{2} / \mathrm{g}$, and the pore size distribution curve maximum was at $24 \mathrm{~nm}$.

\subsection{Study of Biocompatibility}

The biocompatibility of the samples was tested by soaking their granules in all four types of simulated body fluids.

Chemical compositions of the SBFs are summarized in Table 2. (Detailed experimental description of the composition is given in the Supplementary Materials, Table S1). In SBF1, the concentrations were the same as in the original model solution. The concentration of calcium-ion in SBF2 was only $1.25 \mathrm{mmol} / \mathrm{L}$, in order to simulate the effect of the 'free' fraction of calcium ions, which is only about the half of the total calcium concentration in the blood serum [45]. The concentration of calcium ions was increased to $5.0 \mathrm{mmol} / \mathrm{L}$ in the cases of SBF3 and SBF4, to compensate the presence of serum albumin, which binds a portion of calcium ions and works as a calcium ion buffer [45]. In these two solutions, the available 'free' concentration of calcium ions was estimated to be the same as in SBF1. SBF4 had the same chemical composition as SBF3, except the concentration of the hydrogen-carbonate ion, which was increased to $27 \mathrm{mmol} / \mathrm{L}$, to the same level that is present in the human blood plasma. 
Table 2. Chemical compositions of the human blood plasma and applied simulated body fluids SBF1-SBF4.

\begin{tabular}{|c|c|c|c|c|c|c|}
\hline Components & $\begin{array}{l}\text { Blood Plasma } \\
\left(\mathrm{mmol} \cdot \mathrm{L}^{-1}\right)\end{array}$ & $\begin{array}{c}\mathrm{SBF}^{* *} \\
\left(\mathrm{mmol} \cdot \mathrm{L}^{-1}\right)\end{array}$ & $\begin{array}{c}\text { SBF1 } \\
\left(\mathrm{mmol}^{\left.-\mathrm{L}^{-1}\right)}\right.\end{array}$ & $\begin{array}{c}\text { SBF2 } \\
\left(\mathrm{mmol}^{-\mathrm{L}^{-1}}\right)\end{array}$ & $\begin{array}{c}\mathrm{SBF} 3 \\
\left(\mathrm{mmol} \cdot \mathrm{L}^{-1}\right)\end{array}$ & $\begin{array}{c}\text { SBF4 } \\
\left(\mathrm{mmol}^{-1} \mathrm{~L}^{-1}\right)\end{array}$ \\
\hline $\mathrm{Ca}^{2+}$ & 2.5 & 2.5 & 2.50 & 1.26 & 5.01 & 5.02 \\
\hline $\mathrm{HPO}_{4}{ }^{2-}$ & 1 & 1 & 1.00 & 1.00 & 1.00 & 1.00 \\
\hline $\mathrm{Na}^{+}$ & 142 & 142 & 141.98 & 142.02 & 142.02 & 142.03 \\
\hline $\mathrm{Cl}^{-}$ & 103 & 148.5 & 152.83 & 150.60 & 154.55 & 133.46 \\
\hline $\mathrm{Mg}^{2+}$ & 1.5 & 1.5 & 1.50 & 1.50 & 1.51 & 1.50 \\
\hline $\mathrm{K}^{+}$ & 5 & 5 & 5.01 & 5.02 & 4.99 & 5.02 \\
\hline $\mathrm{SO}_{4}^{2-}$ & 0.5 & 0.5 & 0.50 & 0.51 & 0.50 & 0.50 \\
\hline $\mathrm{HCO}_{3}{ }^{-} / \mathrm{CO}_{3}{ }^{2-}$ & 27 & 4.2 & 4.19 & 4.19 & 4.20 & 27.00 \\
\hline TRIS & - & 5 & 5.00 & 5.00 & 5.00 & 5.00 \\
\hline Kanamycin & - & - & 0.21 & 0.21 & 0.21 & 0.21 \\
\hline Gentamicin & - & - & 0.11 & 0.10 & 0.10 & 0.11 \\
\hline Glutamic acid * & $0.05-0.30$ & - & - & - & 0.19 & 0.19 \\
\hline Alanine & $0.31-0.38$ & - & - & - & 0.36 & 0.36 \\
\hline Glycine & $0.11-0.29$ & - & - & - & 0.24 & 0.24 \\
\hline Proline & $0.17-0.21$ & - & - & - & 0.21 & 0.21 \\
\hline Leucine & $0.11-0.16$ & - & - & - & 0.12 & 0.12 \\
\hline Lysine & $0.13-0.18$ & - & - & - & 0.17 & 0.17 \\
\hline Serine & $0.088-0.094$ & - & - & - & 0.09 & 0.09 \\
\hline Valine & $0.19-0.24$ & - & - & - & 0.22 & 0.22 \\
\hline Serum albumin $\left(g \cdot \mathrm{L}^{-1}\right)$ & $35-50$ & - & - & - & 40 & 40 \\
\hline
\end{tabular}

* Average concentrations of amino acids from references [46-48]; ${ }^{* *}$ Original Kokubo's solution, from reference [49].

Figure 2 shows the scanning electron micrographs of surfaces of S1000 before and after soaking in the four simulated body fluids. The effect of the higher temperature on the untreated surfaces cannot be seen on the micrographs at the applied magnification. The difference between the images is the surface of the samples treated at the different temperatures. The surface of the silica matrix of the samples heated at $1050{ }^{\circ} \mathrm{C}$ and $1100{ }^{\circ} \mathrm{C}$ is smoother than that of the samples heated at $1000{ }^{\circ} \mathrm{C}$. The reason for this is the beginning of a viscous flow of the matrix at above $1000{ }^{\circ} \mathrm{C}$. An SEM picture of the surface flow of a sample heated a $1200{ }^{\circ} \mathrm{C}$ is shown in Figure S11. The surface of the control sample seem to be a little bit different due to the sideway orientation of the specimen.

Hydroxyapatite deposition occurred only in SBF1: cauliflower-like globules (orange colored) and appeared on the surface after two weeks. The nature of surface deposit was confirmed by energy dispersive X-Ray (EDX, Bruker Corporation, Billerica, MA, USA) spectroscopy, the scanned area is shown in Figure S8, and the EDX spectrum in Figure S9. There was no precipitation on the sample's surface treated in SBF2, no globules were noticeable. SBF3 contained amino acids and albumin as well. We could not detect any hydroxyapatite deposition in this case either. SBF4 contained albumin and amino acids; and the concentration of the hydrogen carbonate ion was increased to the same level as is in the human blood plasma, $27.0 \mathrm{mmol} / \mathrm{L}$. On the basis of the scanning electron micrographs, we could not detect any visible positive or negative effect of the increased hydrogen carbonate ion concentration. There was no precipitation on the surfaces of the samples calcined at $1050{ }^{\circ} \mathrm{C}$ and $1100{ }^{\circ} \mathrm{C}$ (Figure 3), which may indicate the negative effect of the high calcination temperature. There was no hydroxyapatite precipitation on the control sample's surface either, which indicates the important role of the calcium-rich binding sites in the silica matrix. 


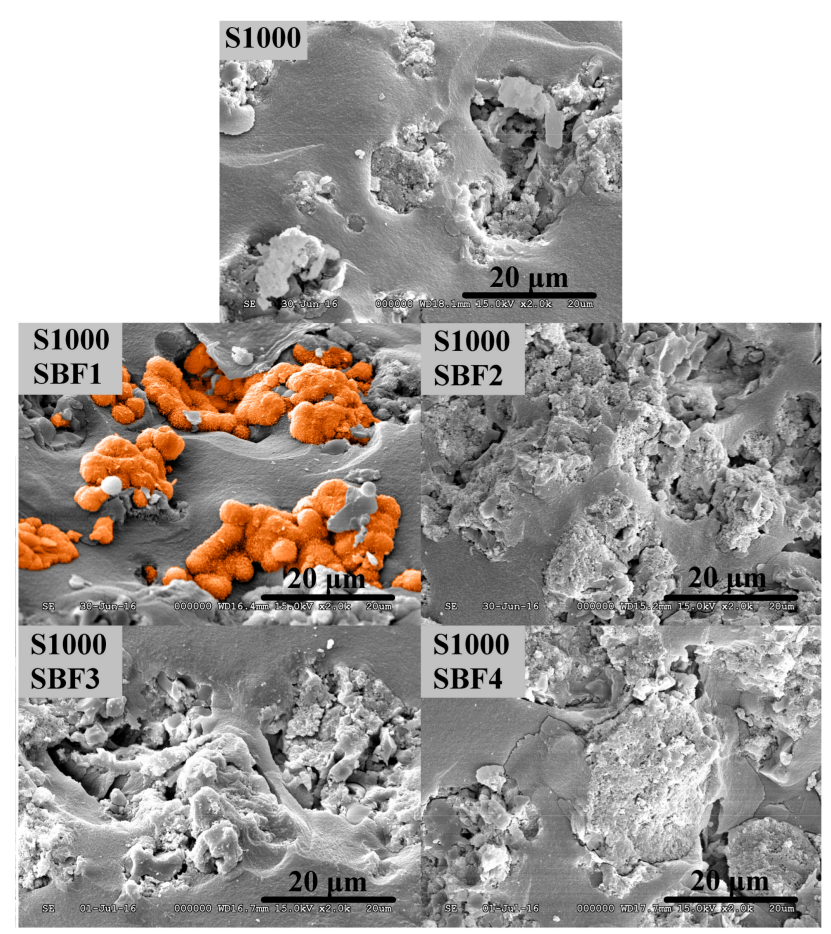

Figure 2. SEM micrographs of the untreated surface of the sample S1000 (top picture) and after soaking in the four types of simulated body fluids. The typical cauliflower-like structure of deposited HA can be seen only on the surface of S1000 treated in SBF1 (orange colored, similar to the ones found in the literature [50-53]).

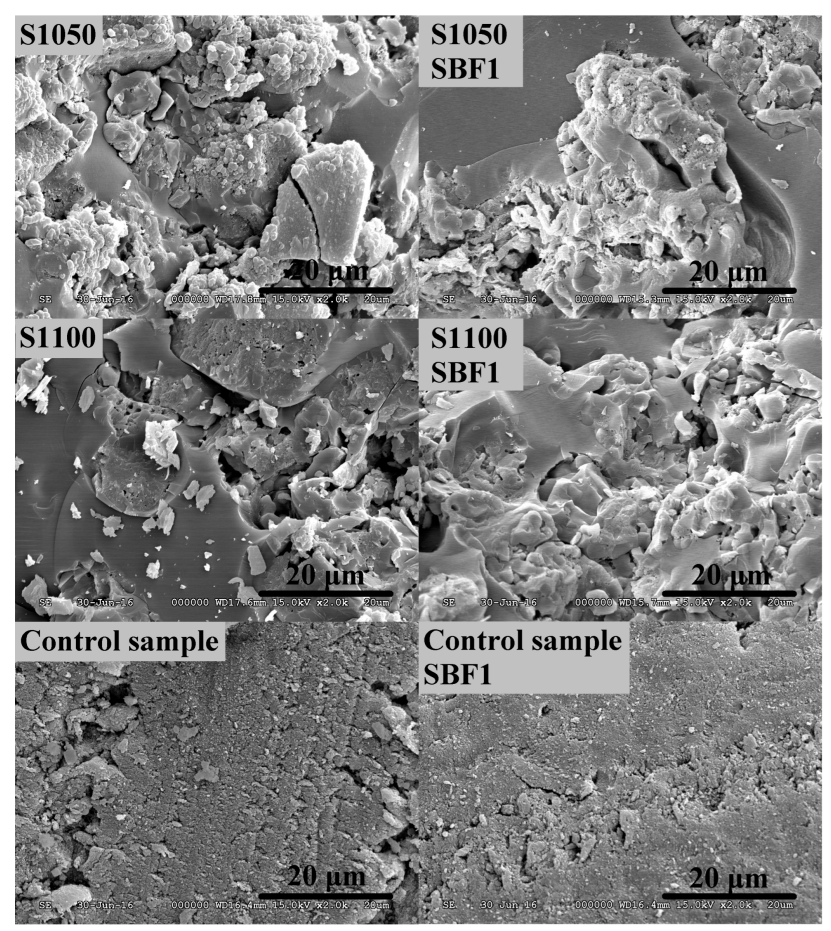

Figure 3. SEM micrographs of the samples calcined at $1050{ }^{\circ} \mathrm{C}(\mathrm{S} 1050)$ and $1100{ }^{\circ} \mathrm{C}(\mathrm{S} 1100)$ and the control sample. There was no hydroxyapatite deposition on the surfaces of the samples.

The scanning electron micrographs of S1050, S1100, and of the control samples treated in SBF2, SBF3, and SBF4 are shown in the Supplementary Materials (Figures S5-S7). 


\section{Discussion}

Specific surface areas and pore size distribution curves of the samples varied significantly with the heating temperature. The samples calcined at $500{ }^{\circ} \mathrm{C}$ had a high specific surface area, and their characteristic pore size could have been determined from the pore size distribution curves. Specific surface areas decreased very significantly when the heating temperature was increased to $1000^{\circ} \mathrm{C}$ and decreased even further by increasing the temperature from 1000 to $1050^{\circ} \mathrm{C}$ and then to $1100{ }^{\circ} \mathrm{C}$.

In order to provide reliable and comparable test results and to avoid false positive or negative effects in the SBF studies, all calcium phosphate-containing samples were cut from the same monolith, as described in the Materials and Methods section. Fluctuations in the chemical composition, as well as morphology differences due to slightly different synthetic/aging/drying conditions, can be eliminated by this method. Hydroxyapatite deposition occurred only in SBF1. Since the solution SBF2 was not supersaturated for any of calcium phosphates, the nucleation did not start in two weeks. Even when we increased the calcium ion concentration to $5.0 \mathrm{mmol} / \mathrm{L}$, there was no hydroxyapatite deposition on the surface of S1000 in the SBF3. In the human blood plasma, the protein-bound calcium concentration is about $1.15 \mathrm{mmol} / \mathrm{L}$ and $90 \%$ of this is bound to albumin. Under normal conditions, only $10 \%$ of the binding sites of the albumin are utilized. When an excess of calcium is loaded, not only the free calcium ion concentration increases in the body fluid, but it also results in a simultaneous increase in the concentration of all calcium-containing species, especially in the protein-bound fraction. Thus, the net change in the free calcium level is significantly lower than expected [45]. The reason for the lack of hydroxyapatite precipitation in SBF4 is the same as in the case of SBF3. Although the total concentration of the calcium ion was $5.0 \mathrm{mmol} / \mathrm{L}$, the free ion concentration was under the supersaturated level due to the presence of the albumin, so the precipitation did not occur within two weeks.

The high calcination temperature may negatively affect the in vitro bioactivity. The silica matrix undergoes a slow, viscous flow and shrinking during the heat treatment and the melted silica can partly cover the calcium-rich binding sites (Figures S10 and S11). Additionally, dehydration of the silica matrix continues at elevated temperatures, resulting in a significant drop in the number of surface functional silanol groups, and a decrease in the rehydration capability of the silica surfaces [54]. Consequently, the surface of the sample changes continuously, the ion exchange process between the surface silanol groups and the model fluid becomes more and more inhibited and that change is mirrored by their in vitro bioactivities.

Nevertheless, studying samples of different chemical compositions can lead to a contradictory result. In a previous study, samples containing only $\beta$-tricalcium phosphate were tested in the original Kokubo's simulated body fluid (SBF). One sample was sintered at $1050^{\circ} \mathrm{C}$ and the other at $1100{ }^{\circ} \mathrm{C}$. After two weeks, a hydroxyapatite layer appeared on the surfaces of both samples (scanning electron micrographs are in the Supplementary Material: Figure S4). The reason for this can be the strong basic character of $\beta$-tricalcium phosphate, which can cause a change in the $\mathrm{pH}$ of the simulated body fluid in the vicinity of the tricalcium phosphate (TCP) particles. Furthermore, it is well known that the solubility of the calcium phosphates decreases at higher $\mathrm{pH}$ [55]. Thus, if the $\mathrm{pH}$ is high enough in the nearly supersaturated solution, spontaneous crystal formation can occur even if the sintered silica aerogel matrix reduces the number of the calcium binding sites.

\section{Conclusions}

New types of simulated body fluids were prepared with improved compositions in order to simulate the content of human blood plasma more precisely. Four types of aerogel-based material were tested in all of the model solutions. The sample, which was referred to be as bioactive according to the results obtained by soaking it in the original model solution, did not show hydroxyapatite formation ability in the modified solutions. The reason for this may be the altering of the calcium ion concentration, which was under the supersaturated level in those solutions. Studies on the effect of the calcination temperature confirmed that the samples treated at $1050{ }^{\circ} \mathrm{C}$ or above do not show in vitro bioactivity. Nevertheless, if we study samples which possess only calcium phosphate in the 
matrix, we obtain contradictory results. This can be explained by the strong basic character of the calcium phosphate, by which the $\mathrm{pH}$ may increase in the simulated body fluid under static, unstirred conditions. Regarding the increased $\mathrm{HCO}_{3}{ }^{-}$ion concentration, we could not detect any positive or negative effect.

Obviously, the lack of the hydroxyapatite deposition in the modified body fluids is in good agreement with the behavior of the living organisms. In vivo, hydroxyapatite layer formation occurs only in the active cellular remodelling phase of the bone tissues, and no hydroxyapatite is formed spontaneously just by contact with the blood serum. Furthermore, the same types of aerogel-based ceramic materials were studied in vivo earlier in a series of animal experiments and showed excellent bioactivities in rats [56,57]. From the results, we must conclude that the better we approach the physiological conditions, the less reliable the in vitro tests are, and it is not recommended to rank or sort off the artificial bone substitute materials only on the basis of their in vitro performances.

Supplementary Materials: The following are available online at www.mdpi.com/link, Figure S1: Pictures of the obtained aerogels after the supercritical drying process. The control samples (a), contained only cellulose as additive. The rightward barrels (b) contained cellulose, tricalcium phosphate and hydroxyapatite. The additives are distributed homogeneously in both samples, Figure S2: Scanning electron micrograph of an infected sample from an earlier experiment. Due to the non-sterile conditions, unicellular microbes - for example Pseudomonas aeruginosa or Escherichia coli (blue coloured) - appeared on the surface of the sample, Figure S3: Nitrogen adsorption-desorption isotherms of the studied samples. The samples sintered at $500{ }^{\circ} \mathrm{C}$ adsorbed great amount of nitrogen ( $a$ and $b$ ), while with the increasing sintering temperature the volume of the adsorbed gas decreases progressively (c and d). The samples possessed porous structure even after sintering at $110{ }^{\circ} \mathrm{C}(\mathrm{e})$, although both the specific surface area and the pore diameter decreased significantly. The control sample (f) did not contain any additive, that is why it adsorbed more nitrogen gas and so had greater specific surface area then the sample S1000 sintered at the same temperature, Figure S4: Scanning electron micrographs of aerogel bioceramic samples containing calcium-phosphate. The samples, sintered at $1050{ }^{\circ} \mathrm{C}(\mathbf{a})$ and $1100^{\circ} \mathrm{C}(\mathbf{b})$, were soaked in simulated body fluid for two weeks. Hydroxyapatite with the typical cauliflower like structures (orange coloured) appeared on the surfaces of both samples. SEM EDX identification of the surface deposit is shown in Figure S8 and Figure S9, Figure S5: SEM micrographs of the samples soaked in SBF2. Due to the low effective calcium ion concentration, there was no hydroxyapatite deposition after 14 days, Figure S6: The SEM micrographs of the samples treated in SBF3. Due to the calcium complex formation property of serum albumin and the amino acids, there was no hydroxyapatite precipitation after two weeks, Figure S7: The SEM micrographs of the samples treated in SBF4. There was no hydroxyapatite deposition after fourteen days. The reason of this is the same as in case of SBF3, the albumin acted like a buffer and decreased the free calcium ion concentration. Thereby the solution was not supersaturated, the nucleation did not occur, Figure S8: SEM picture of HA surface deposits on an aerogel-based biocomposite material formed in the original Kokubo's simulated body fluid. White rectangele indicate placement of EDX beam. Spectra recorded for the area is given in Figure S9, Figure S9: EDX spectrum of the surface deposit area indicted by a white rectangle in Figure S8. Ca and P peaks are characteristic and intense, while Si peak is relatively low. The intensity of silicon peak is variable in such samples in general, as the base silica aerogel layer is also excited, Figure S10: SEM picture of the silica aerogel matrix of artificial bone substitute materials in $8 \mathrm{k}$ and $64 \mathrm{k}$ magnification. Mesoporous nanostructure and overlapping 50-70 nm secondary globuli are shown in the right picture. The porous fine structure clearly demonstrates the basic difference between aerogel-based and traditional ceramic-based bioactive artificial bone substitute materials, Figure S11: SEM picture indicates that the high temperature $\left(1200^{\circ} \mathrm{C}\right)$ viscous flow of silica aerogel that covers the entire surface of HA and TCP particles in the composite material, Table S1: Chemical compositions of the prepared simulated body fluids.

Acknowledgments: The authors thank the Hungarian Science Foundation (OTKA, NK 105156) for financial support. The research was supported by the TÁMOP-4.2.2.A-11/1/KONV-2012-0036 and the GINOP-2.2.1-15-2017-00068 project. The work was co-financed by the European Union and the European Social Fund.

Author Contributions: I.L. initiated the project, E.G. and I.L. designed and performed the experiments; E.G., I.L. and I.F. analyzed the data; I.F. and I.L. contributed reagents; E.G. and I.L. wrote the paper.

Conflicts of Interest: The authors declare no conflict of interest.

\section{References}

1. Luetke, A.; Meyers, P.A.; Lewis, I.; Juergens, H. Osteosarcoma treatment-Where do we stand? A state of the art review. Cancer Treat. Rev. 2014, 40, 523-532. [CrossRef] [PubMed]

2. Jing, W.; Smith, A.A.; Liu, B.; Li, J.; Hunter, D.J.; Dhamdhere, G.; Salmon, B.; Jiang, J.; Cheng, D.; Johnson, C.A.; et al. Reengineering autologous bone grafts with the stem cell activator WNT3A. Biomaterials 2015, 47, 29-40. [CrossRef] [PubMed] 
3. Torres, J.; Tamimi, I.; Cabrejos-Azama, J.; Tresguerres, I.; Alkhraisat, M.; López-Cabarcos, E.; Hernández, G.; Tamimi, F. Monetite granules versus particulate autologous bone in bone regeneration. Ann. Anat. Anat. Anz. 2015, 200, 126-133. [CrossRef] [PubMed]

4. Kolk, A.; Handschel, J.; Drescher, W.; Rothamel, D.; Kloss, F.; Blessmann, M.; Heiland, M.; Wolff, K.-D.; Smeets, R. Current trends and future perspectives of bone substitute materials-From space holders to innovative biomaterials. J. Cranio-Maxillofac. Surg. 2012, 40, 706-718. [CrossRef] [PubMed]

5. Jones, J.R. New trends in bioactive scaffolds: The importance of nanostructure. J. Eur. Ceram. Soc. 2009, 29, 1275-1281. [CrossRef]

6. Wei, C.-K.; Ding, S.-J. Acid-resistant calcium silicate-based composite implants with high-strength as load-bearing bone graft substitutes and fracture fixation devices. J. Mech. Behav. Biomed. Mater. 2016, 62, 366-383. [CrossRef] [PubMed]

7. Van der Stok, J.; Van Lieshout, E.M.M.; El-Massoudi, Y.; Van Kralingen, G.H.; Patka, P. Bone substitutes in the Netherlands-A systematic literature review. Acta Biomater. 2011, 7, 739-750. [CrossRef] [PubMed]

8. Abdal-hay, A.; Hamdy, A.S.; Khalil, K.A.; Lim, J.H. A novel simple in situ biomimetic and simultaneous deposition of bonelike apatite within biopolymer matrix as bone graft substitutes. Mater. Lett. 2014, 137, 260-264. [CrossRef]

9. Liu, C.; Wan, P.; Tan, L.L.; Wang, K.; Yang, K. Preclinical investigation of an innovative magnesium-based bone graft substitute for potential orthopaedic applications. J. Orthop. Transl. 2014, 2, 139-148. [CrossRef]

10. Blokhuis, T.J. Bioresorbable bone graft substitutes. In Bone Substitute Biomaterials; Woodhead Publishing: Amsterdam, The Netherlands, 2014; pp. 80-92.

11. Lacroix, J.; Jallot, E.; Lao, J. Gelatin-bioactive glass composites scaffolds with controlled macroporosity. Chem. Eng. J. 2014, 256, 9-13. [CrossRef]

12. Vernè, E.; Ferraris, S.; Vitale-Brovarone, C.; Cochis, A.; Rimondini, L. Bioactive glass functionalized with alkaline phosphatase stimulates bone extracellular matrix deposition and calcification in vitro. Appl. Surf. Sci. 2014, 313, 372-381. [CrossRef]

13. Bellucci, D.; Sola, A.; Salvatori, R.; Anesi, A.; Chiarini, L.; Cannillo, V. Sol-gel derived bioactive glasses with low tendency to crystallize: Synthesis, post-sintering bioactivity and possible application for the production of porous scaffolds. Mater. Sci. Eng. C 2014, 43, 573-586. [CrossRef] [PubMed]

14. Chen, X.; Chen, X.; Brauer, D.S.; Wilson, R.M.; Hill, R.G.; Karpukhina, N. Novel alkali free bioactive fluorapatite glass ceramics. J. Non-Cryst. Solids 2014, 402, 172-177. [CrossRef]

15. Durgalakshmi, D.; Subhathirai, S.P.; Balakumar, S. Nano-bioglass: A Versatile Antidote for Bone Tissue Engineering Problems. Procedia Eng. 2014, 92, 2-8. [CrossRef]

16. Mutlu, I. Sinter-coating method for the production of TiN-coated titanium foam for biomedical implant applications. Surf. Coat. Technol. 2013, 232, 396-402. [CrossRef]

17. Rivard, J.; Brailovski, V.; Dubinskiy, S.; Prokoshkin, S. Fabrication, morphology and mechanical properties of Ti and metastable Ti-based alloy foams for biomedical applications. Mater. Sci. Eng. C 2014, 45, 421-433. [CrossRef] [PubMed]

18. Butev, E.; Esen, Z.; Bor, S. In vitro bioactivity investigation of alkali treated Ti6Al7Nb alloy foams. Appl. Surf. Sci. 2015, 327, 437-443. [CrossRef]

19. Fidancevska, E.; Ruseska, G.; Bossert, J.; Lin, Y.-M.; Boccaccini, A.R. Fabrication and characterization of porous bioceramic composites based on hydroxyapatite and titania. Mater. Chem. Phys. 2007, 103, 95-100. [CrossRef]

20. Miculescu, F.; Mocanu, A.-C.; Dascălu, C.A.; Maidaniuc, A.; Batalu, D.; Berbecaru, A.; Voicu, S.I.; Miculescu, M.; Thakur, V.K.; Ciocan, L.T. Facile synthesis and characterization of hydroxyapatite particles for high value nanocomposites and biomaterials. Vacuum 2017, 146, 614-622. [CrossRef]

21. Miculescu, F.; Maidaniuc, A.; Voicu, S.I.; Thakur, V.K.; Stan, G.E.; Ciocan, L.T. Progress in Hydroxyapatite-Starch Based Sustainable Biomaterials for Biomedical Bone Substitution Applications. ACS Sustain. Chem. Eng. 2017, 5, 8491-8512. [CrossRef]

22. Izquierdo-Barba, I.; Colilla, M.; Vallet-Regí, M. Nanostructured Mesoporous Silicas for Bone Tissue Regeneration. J. Nanomater. 2008, 2008, e106970. [CrossRef]

23. Parekh, B.; Joshi, M.; Vaidya, A. Characterization and inhibitive study of gel-grown hydroxyapatite crystals at physiological temperature. J. Cryst. Growth 2008, 310, 1749-1753. [CrossRef] 
24. Walschus, U.; Hoene, A.; Neumann, H.-G.; Wilhelm, L.; Lucke, S.; Lüthen, F.; Rychly, J.; Schlosser, M. Morphometric immunohistochemical examination of the inflammatory tissue reaction after implantation of calcium phosphate-coated titanium plates in rats. Acta Biomater. 2009, 5, 776-784. [CrossRef] [PubMed]

25. Hannink, G.; Arts, J.J.C. Bioresorbability, porosity and mechanical strength of bone substitutes: What is optimal for bone regeneration? Injury 2011, 42 (Suppl. S2), S22-S25. [CrossRef] [PubMed]

26. Lu, Y.; Cao, G.; Kale, R.P.; Prabakar, S.; López, G.P.; Brinker, C.J. Microporous Silica Prepared by Organic Templating: Relationship between the Molecular Template and Pore Structure. Chem. Mater. 1999, 11, 1223-1229. [CrossRef]

27. Karageorgiou, V.; Kaplan, D. Porosity of 3D biomaterial scaffolds and osteogenesis. Biomaterials 2005, $26,5474-5491$. [CrossRef] [PubMed]

28. Müller, L.; Müller, F.A. Preparation of SBF with different content and its influence on the composition of biomimetic apatites. Acta Biomater. 2006, 2, 181-189. [CrossRef] [PubMed]

29. Kokubo, T.; Takadama, H. How useful is SBF in predicting in vivo bone bioactivity? Biomaterials 2006, 27, $2907-2915$. [CrossRef] [PubMed]

30. Kang, Y.; Xu, X.; Yin, G.; Chen, A.; Liao, L.; Yao, Y.; Huang, Z.; Liao, X. A comparative study of the in vitro degradation of poly(L-lactic acid) / $\beta$-tricalcium phosphate scaffold in static and dynamic simulated body fluid. Eur. Polym. J. 2007, 43, 1768-1778. [CrossRef]

31. Towler, M.R.; Boyd, D.; Freeman, C.; Brook, I.M.; Farthing, P. Comparison of in vitro and in vivo Bioactivity of $\mathrm{SrO}-\mathrm{CaO}-\mathrm{ZnO}-\mathrm{SiO}_{2}$ Glass Grafts. J. Biomatrial Appl. 2009, 23. [CrossRef] [PubMed]

32. Wu, C.; Zhang, Y.; Fan, W.; Ke, X.; Hu, X.; Zhou, Y.; Xiao, Y. CaSiO3 microstructure modulating the in vitro and in vivo bioactivity of poly(lactide-co-glycolide) microspheres. J. Biomed. Mater. Res. A 2011, 98A, 122-131. [CrossRef] [PubMed]

33. Abou Neel, E.A.; Mizoguchi, T.; Ito, M.; Bitar, M.; Salih, V.; Knowles, J.C. In vitro bioactivity and gene expression by cells cultured on titanium dioxide doped phosphate-based glasses. Biomaterials 2007, 28, 2967-2977. [CrossRef] [PubMed]

34. Wang, P.; Liu, X.; Zhao, L.; Weir, M.D.; Sun, J.; Chen, W.; Man, Y.; Xu, H.H.K. Bone tissue engineering via human induced pluripotent, umbilical cord and bone marrow mesenchymal stem cells in rat cranium. Acta Biomater. 2015, 18, 236-248. [CrossRef] [PubMed]

35. Zhang, Z.-Y.; Teoh, S.-H.; Hui, J.H.P.; Fisk, N.M.; Choolani, M.; Chan, J.K.Y. The potential of human fetal mesenchymal stem cells for off-the-shelf bone tissue engineering application. Biomaterials 2012, 33, 2656-2672. [CrossRef] [PubMed]

36. Wittenburg, G.; Flade, V.; Garbe, A.I.; Lauer, G.; Labudde, D. Scaffold preferences of mesenchymal stromal cells and adipose-derived stem cells from green fluorescent protein transgenic mice influence the tissue engineering of bone. Br. J. Oral Maxillofac. Surg. 2014, 52, 409-414. [CrossRef] [PubMed]

37. Wen, Y.; Gu, W.; Cui, J.; Yu, M.; Zhang, Y.; Tang, C.; Yang, P.; Xu, X. Platelet-rich plasma enhanced umbilical cord mesenchymal stem cells-based bone tissue regeneration. Arch. Oral Biol. 2014, 59, 1146-1154. [CrossRef] [PubMed]

38. Zeng, H.; Chittur, K.K.; Lacefield, W.R. Analysis of bovine serum albumin adsorption on calcium phosphate and titanium surfaces. Biomaterials 1999, 20, 377-384. [CrossRef]

39. Wassell, D.T.H.; Hall, R.C.; Embery, G. Adsorption of bovine serum albumin onto hydroxyapatite. Biomaterials 1995, 16, 697-702. [CrossRef]

40. Dorozhkin, S.V.; Dorozhkina, E.I. The influence of bovine serum albumin on the crystallization of calcium phosphates from a revised simulated body fluid. Colloids Surf. Physicochem. Eng. Asp. 2003, 215, 191-199. [CrossRef]

41. Kistler, S.S. Coherent Expanded Aerogels and Jellies: Abstract: Nature. Available online: http://www. nature.com/nature/journal/v127/n3211/abs/127741a0.html (accessed on 22 December 2016).

42. Lázár, I.; Bereczki, H.F.; Manó, S.; Daróczi, L.; Deák, G.; Fábián, I.; Csernátony, Z. Synthesis and study of new functionalized silica aerogel poly(methyl methacrylate) composites for biomedical use. Polym. Compos. 2015, 36, 348-358. [CrossRef]

43. Lázár, I.; Fábián, I. A Continuous Extraction and Pumpless Supercritical $\mathrm{CO}_{2}$ Drying System for Laboratory-Scale Aerogel Production. Gels 2016, 2, 26. [CrossRef]

44. Vallés Lluch, A.; Gallego Ferrer, G.; Monleón Pradas, M. Biomimetic apatite coating on P(EMA-co-HEA)/SiO2 hybrid nanocomposites. Polymer 2009, 50, 2874-2884. [CrossRef] 
45. Clark, V.L.; Kruse, J.A. Clinical Methods: The History, Physical, and Laboratory Examinations, 3rd ed.; Walker, H.K., Hall, W.D., Hurst, J.W., Eds.; Butterworths: Boston, MA, USA, 1990.

46. Metabolic \& Therapeutic Aspects of Amino Acids in Clinical Nutrition, Second Edition. Available online: https: / / www.crcpress.com/Metabolic--Therapeutic-Aspects-of-Amino-Acids-in-Clinical-NutritionSecond/Cynober/p/book/9780849313820 (accessed on 9 November 2017).

47. Steele, B.F.; Reynolds, M.S.; Baumann, C.A. Amino acids in the blood and urine of human subjects ingesting different amounts of the same proteins. J. Nutr. 1950, 40, 145-158. [PubMed]

48. Stein, W.H.; Moore, S. The free amino acids of human blood plasma. J. Biol. Chem. 1954, 211, 915-926. [PubMed]

49. Li, H.; Li, Z.-X.; Li, H.; Wu, Y.-Z.; Wei, Q. Characterization of plasma sprayed hydroxyapatite $/ \mathrm{ZrO}_{2}$ graded coating. Mater. Des. 2009, 30, 3920-3924. [CrossRef]

50. Aljabo, A.; Abou Neel, E.A.; Knowles, J.C.; Young, A.M. Development of dental composites with reactive fillers that promote precipitation of antibacterial-hydroxyapatite layers. Mater. Sci. Eng. C 2016, 60, $285-292$. [CrossRef] [PubMed]

51. Chen, L.J.; Wang, M. Production and evaluation of biodegradable composites based on PHB-PHV copolymer. Biomaterials 2002, 23, 2631-2639. [CrossRef]

52. Ni, J.; Wang, M. In vitro evaluation of hydroxyapatite reinforced polyhydroxybutyrate composite. Mater. Sci. Eng. C 2002, 20, 101-109. [CrossRef]

53. Jaakkola, T.; Rich, J.; Tirri, T.; Närhi, T.; Jokinen, M.; Seppälä, J.; Yli-Urpo, A. In vitro Ca-P precipitation on biodegradable thermoplastic composite of poly( $\varepsilon$-caprolactone-co-DL-lactide) and bioactive glass (S53P4). Biomaterials 2004, 25, 575-581. [CrossRef]

54. Barrie, P.J. NMR Applications to Porous Solids. In Annual Reports on NMR Spectroscopy; Webb, G.A., Ed.; Academic Press: Oxford, MA, USA, 1995; Volume 30, pp. 37-95.

55. Mekmene, O.; Quillard, S.; Rouillon, T.; Bouler, J.-M.; Piot, M.; Gaucheron, F. Effects of pH and Ca/P molar ratio on the quantity and crystalline structure of calcium phosphates obtained from aqueous solutions. Dairy Sci. Technol. 2009, 89, 301-316. [CrossRef]

56. Szabó, B.A.; Kiss, L.; Manó, S.; Jónás, Z.; Lázár, I.; Fábián, I.; Dezső, B.; Csernátony, Z. The examination of aerogel composite artificial bone substitutes in animal models. Biomech. Hung. 2013, 52-63. [CrossRef]

57. Kuttor, A.; Szalóki, M.; Rente, T.; Kerényi, F.; Bakó, J.; Fábián, I.; Lázár, I.; Jenei, A.; Hegedüs, C. Preparation and application of highly porous aerogel-based bioactive materials in dentistry. Front. Mater. Sci. 2014, 8, 46-52. [CrossRef] 